\title{
"MÉTOdOS E TÉCNICAS DE PESQUISA EM PSICOLOGIA"
}

\author{
Nicodemos Batista BORGES*
}

O livro "Métodos e Técnicas de Pesquisa em Psicologia" foi a última obra, das diversas, escritas pelo Luiz Fernando de Lara Campos, nascido em 1962, graduado em 1986 e Doutor pela USP (1994), que infelizmente veio a falecer no final de 1999 num acidente de carro, antes mesmo desta ser publicada.

O autor começa o livro retornando,através do contexto histórico, à evolução da psicologia como ciência, apontando os acertos e erros ocorridos nessa evolução. Convida o leitor a uma reflexão sobre a ciência psicologia, seu desenvolvimento no Brasil e no mundo, as influências de outras ciências (Biologia, Física, etc), o que deve ou não ser considerado como ciência, suas mudanças. Convocar também os futuros profissionais da área a adaptar a psicologia brasileira aos padrões internacionais, resgatando o tempo e o respeito que a psicologia perdeu no nosso país.

No primeiro capítulo, Campos faz uma rápida explanação sobre conhecimentos: empíricos, religiosos, filosóficos e científicos. Mostra, suas estruturas e suas diferenças, para isso utilizando-se, além de uma linguagem de simples compreensão, do auxílio de um quadro que apresenta as características de cada conhecimento. Chama a atenção para as pseudociências, que, apesar de possuírem semelhanças com a ciência, não podem ser consideradas como tal, pois partem de hipóteses centrais que são dogmáticas. Dá claras definições sobre o que é ciência e levanta a importância de se separar os valores pessoais dos valores científicos e profissionais.

Dando continuidade ao livro, é dada a definição de método científico, sua importância para a pesquisa, além de apontar e exemplificar tópicos necessários para que o método seja considerado científico. Ainda neste capítulo é definida pesquisa, seus principais tipos (descritivas e experimentais); as diferenças entre uma pesquisa longitudinal e transversal; quanto à origem ou local, em que serão colhidos os dados (pesquisas: documental, de campo ou laboratorial); as vantagens de fazer uma pesquisa quantitativa ou qualitativa; as definições e validações de uma pesquisa, tudo com o auxílio de exemplos e esquemas, facilitando a compreensão do leitor.

No terceiro capítulo, o autor orienta na formulação do tema, do problema a ser questionado, dos objetivos gerais e específicos de uma pesquisa. Classifica a questão a ser levantada e qual o tipo de pesquisa que melhor se adapta a ela. Refere-se a tipos e condições que são necessárias para a formulação de uma hipótese e termina, de maneira sucinta, chamando a atenção para a escolha do método a ser utilizado na pesquisa, esclarecendo a importância de escolhê-lo não com o intuito de provar a sua hipótese e sim de respondê-la.

Em sua obra, Campos levanta a importância de controlar e manipular as variáveis e sua classificação. Frisa as possíveis relações da variável com o tempo. Fala sobre os tipos e

${ }^{(*)}$ Graduando da Faculdade de Psicologia da UNISA - Universidade de Santo Amare.

Endereço para contato: Rua Antônio Ambuba, 80 - casa 66 - Horto do Ipê

CEP 05782-370 - São Paulo - S.P. Tel.: 5511-4925 / Cel.: 9386-4660

E-mail: borgesnb@ig.com.br 
níveis de mensuração e explana sobre a falta de estudosexperimentaisempaísessubdesenvolvidos cientificamente.

O capítulo cinco traz uma amostragem dos principais delineamentos de pesquisa com suas definições, classificações e seus graus de validações, tudo deforma esclarecedora para o leitor.

O penúltimo capítulo é a montagem de todas as peças do quebra-cabeça que até então estavam sendo esmiuçadas pelo autor, a título de melhor descrevê-las. Neste, o autor nos orienta como tecer passo a passo a pesquisa científica, mostrando todos os pontos necessários para a confecção da mesma.

Campos encerra o livro detalhando as etapas para elaboração de um projeto de pesquisa e paraum relatório de pesquisa. Mostra a importância da escolha das palavras-chave, da abordagem a ser escolhida além de chamar a atenção para o referencial bibliográfico válido.

Para finalizar esta magnífica obra, que eu nomeio de "manual de iniciação científica", os apêndices são um verdadeiro complemento para o leitor.

A obra é desenvolvida com um linguajar de simples compreensão, toda exemplificada, $\mathrm{e}$ detalhada. Serve como um excelente orientador para os estudantes de psicologia, na confecção da monografia e de trabalhos cientíícos, não se reduzindo somente a este papel; é um constante convite à reflexão, como, por exemplo: o que é ciência, como está a psicologia principalmente no Brasil, o que devemos fazer para resgatar a imagem da psicologia no Brasil, além de diversas outras. 